\title{
Life in the balance: \\ My journey with breast cancer*
}

Marla Shapiro, $\mathrm{MD}^{(1)}$

What happens when the doctor becomes patient? Dr. Marla Shapiro, a Canadian physician, on air medical expert for CTV network, health contributor to Canada AM, editor of ParentsCanada, contributor to many other publications, former host of her own show Balance: Television for living well and health columnist for The Globe and Mail gives her perspective on life on the other side of the examining table.

$\mathrm{I}_{\mathrm{d}}^{\mathrm{t}}$ was a routine mammogram, but when the X-ray was done, the radiologist asked for a magnified view of my right breast. She needed to get a better look at something. I wasn't anxious. I knew that this was fairly routine. If the breast tissue is dense, the X-ray film can be difficult to interpret. But when she came back, the news wasn't good. She tried to be reassuring, but her eyes were fixed on the floor as she suggested that I undergo a biopsy.

I could feel the fear rising. I knew I was in trouble. After all, I am a doctor too.

On Friday, August 13, 2004, without warning, I switched roles and became a patient. It was foreign territory for me, and in retrospect, having spent 14 months there, I have to admit the journey was not easy.

The biopsy led to surgery that ultimately confirmed I was suffering from invasive breast cancer.

In many ways, where Dr. Marla ended and just Marla began was poorly defined. My profession was inextricably woven into the very fabric of who I was -someone taught to be a clear thinker and problem solver whose decisions are based on evidence, even if it's just the best that science can offer at the moment.

And when it comes to cancer, the evidence is staggering. It is said that one in every four Canadians will die from some form of the disease and that it will attack $45 \%$ of men and $39 \%$ of women. ${ }^{1}$ Among women, breast cancer is the most common and affects one woman in every nine. Each week in Canada, 431 new cases are diagnosed, and each week, 102 women who have already been diagnosed, die. ${ }^{2}$ As a doctor, you learn to respect those numbers and screen as effectively as you can, be it clinical examination, diagnostic tests or lifestyle counseling. As a patient, your life is changed forever. And mine has.

As well as the feelings everyone has when faced with a life-threatening diagnosis, I had to deal with the fact that, thanks to my appearances both on Canada $A M$ and on Balance, my own show, I am a public figure in my country.

Just what this meant was driven home the day I went for my first oncology appointment. As my husband, Bobby, and I stood at the reception desk in Toronto's Sunnybrook Hospital, we could see that Balance was playing on the television set in the waiting room. People behind us began to wonder out loud if "that woman standing there" was Doctor Marla and if "she" had cancer.

I wanted to turn around and scream, "I may have cancer, but I'm not deaf." And yet I realized at the same

\footnotetext{
* This article was adapted from the original version published in The Globe and Mail, October 5, 2005.

(I) Department of Family and Community Medicine, University of Toronto, Canada.

Address reprint requests to: Dr. Marla Shapiro. Department of Family and Community Medicine, University of Toronto. 602-75 The Donway West. Toronto, Ontario M3C 2E9 Canada. E-mail:MarlaMD@aol.com
} 
time that I'd have to say something about what I was going through. Keeping it a secret was the last thing I wanted. My goal was to deliver a message: Fight and hope. I wanted to support my family and friends with encouraging words.

So, when I wrote the first of my weekly columns for The Globe and Mail's health page in October of 2004, I introduced myself to readers with the news of my recent diagnosis.

I also explained that I did not want the disease to define me, but clearly it has in many ways, some perceptible and some not. I am not the same woman who walked through the doors of mammography that fateful day.

For one thing, the treatment meant that I couldn't practice medicine. I did not want to abandon this role I felt so comfortable with-I felt like my identity was being stripped away. But chemotherapy wipes out your whiteblood- cell count and makes you highly vulnerable to any infection; to keep working in such a situation would have been like doing the tango in a minefield.

I forced myself to keep up with Canada $A M$ and my other media commitments. Ineeded to hold on to a piece of me that was old and familiar. But most of my energy went into fighting the disease.

People ask if this fight has gone better for me because I'm an informed patient. I really don't know. In so many ways, it has been easier because I understand the language and the uncertainty. But in other ways, I know too much and yet not enough. It is very hard ever to feel reassured.

The treatment of breast cancer is tailored to the individual and based on where you are when you are diagnosed. But even then, there are many options and no black and white, no right answer. As I navigated through the maze of diagnosis and treatment options, I realized that, despite my knowledge, I was totally unprepared. It felt like I was running a race. There are so many decisions that have to be made -and made quickly. The various treatment options were outlined, along with the potential benefits and side effects, but ultimately I had to make the choices that I hoped were right for me.

And these choices hinged on the fact that my tests could not confirm whether the areas where the cancer had invaded my body were related to or independent of each other. As a result, I was offered chemotherapy -although I could have refused that option. After that, I had to decide between radiation and mastectomy, therapies that were considered equally effective even if they are clearly so different. I eventually opted for a bilateral mastectomy and reconstruction.
So no one could tell me how to run the race. It's something you have to figure out yourself... what treatments are right for you, what your comfort level is, what risks you' re willing to take. It's a race I had to run alone. Or so I thought.

When my husband and I told our two older children, daughters Jenna and Amanda, I minimized my concern. But when I was to start chemotherapy, I could not shield them from the obvious side effects I would have to endure.

We waited a while to tell nine-year-old Matt, and thought we had done a good job of protecting him. But children are perceptive, and he soon sensed that something was wrong, which frightened him because our silence suggested there was something that he could not talk about.

Once told, he was obviously relieved, and being so young, he soon came up with every conceivable question. He found it curious that I would lose my hair. (Actually, I did too.) He wanted to know if cancer would just go away, like a cold does. When we told him it was something that had to be beaten, he walked around for days, boxing imaginary demons in the air.

Also, suddenly I was home a lot. My children have grown up in a busy household with a mother who leaves early and often comes home late. And while they knew that I was always "there for them," it wasn't always a physical presence. Being there for car pools, events and homework often required a juggling act.

My newfound free time allowed me to rediscover my kitchen. I started baking and cooking so much that, after a while, the kids complained they were gaining weight even as I was gradually disappearing into the side effects of my treatment.

Thanksgiving that year came right after my first round of chemotherapy, and I was unbelievably sick. Nothing had prepared me for how ill I would be. I felt like a toxic waste dump. I couldn't move, I couldn't eat.

Home from school for the weekend, the girls were confronted with just how ill I had become. The fear in their eyes hit me like a ton of bricks. Clearly this wasn't just about me. This was their fight too.

As I tried to suppress my dark thoughts about not being around to see them marry, have children and move through life, I suddenly realized that they had the exact same fears. And while I felt I could force myself to deal with anything, I could barely cope with their pain and fear. Try as I might, I could not make it go away. But as time went by, I found there were things I could do.

The e-mail and letters of support and concern I received were overwhelming. I am eternally grateful 
to the women who came forward to share their stories. I did not have to be alone.

Then one day my husband asked me why, if one in nine of us has breast cancer, does Canada not have more bald women running around?

The answer is that we are here but often silent. We carry on. We wear our wigs. We move forward as best we can, considering so little is said about how nothing in life prepares you to deal with a curve ball like this.

But when I was invited to go to Vancouver to appear on Vicki Gabereau, a popular Canadian talk show viewed widely in Canada, I wondered about leaving the wig at home. The truth was that I was wearing it only on Canada AM. In real life, I walked around bald. I gave speeches bald, went to dinner bald. But I knew that this was different: national television without a wig. I decided that this was who I was in real life, and so I headed off to the West Coast wearing just my little black hat to keep me warm.

As I sat in makeup and Vicki came in to say hello, she stopped and, in her typical way, said: "You look different...." She smiled, I smiled, and off we went to do the interview. She was frank and curious and asked tough questions.

I was totally comfortable in my own skin -and totally unprepared for what happened next: letters came from women saying they had taken off their wigs after seeing the show.

I realized then that many people had thought I was sailing through my fight with cancer, that somehow I had the inside track. In reality, on many levels, it was exactly the opposite: I am no different from anyone else in the same situation.

It soon became apparent to me that I had a story to share -and it wasn't as much about the medicine and scientific advances as it was about the impact on my family, my life and all the things we don't talk about. I became an accidental advocate and continue to share this story, as I did in Mexico City in November of 2008. ${ }^{3}$

When I spoke to CTV, the network I work for, about making a documentary, they were protective of me and said it was my decision, but I felt strongly that I wanted to do this. A crew more or less moved in and followed me around. My family, friends and physicians were open and honest, and the result is called Run Your Own Race and aired for the first time in October of 2005.

I also wrote a book, Life in the Balance: My journey with breast cancer which is a personal account of my experience with the disease and the life-altering decisions that I made. It is also a story of how my family, my friends and health care professionals worked with me and beside me throughout. ${ }^{4}$

Today, my chemotherapy is behind me. The surgeries I elected to have rather than radiation are over, and I have gone back to my office and a career in family medicine that I love.

So how have I changed? In many ways, I am the same -juggling a zillion work balls and loving the return. But in so many other ways, I am different. The only word I can think of to describe it is mindful. I am so much more mindful of the decisions I make, my family, my children and how I choose to live my life. My children would say that my values have changed, and perhaps they are wiser than their mother, who has finally learned to match her emotional and her time commitments.

There are those who insist that I have inspired them with my so-called courage, when, in fact, they have inspired me with their stories. It doesn't take courage to fight when there is no other option. I am not alone. You are not alone. Together, we all make a difference.

\section{References}

I. Canadian Cancer Society. [Consulted January 20, 2008]. Available at: http://www.cancer.ca/Canada-wide/About\%20cancer/Cancer\%20statistics/ Stats\%20at\%20a\%20glance/General\%20cancer\%20stats.aspx?sc_lang=en. 2. Canadian Cancer Society. [Consulted January 20, 2008]. Available at: http://www.cancer.ca/canada-wide/about\%20cancer/cancer\%20statistics/ stats\%20at\%20a\%20glance/breast\%20cancer.aspx?sc_lang=en. 3. International Seminar "Breast Cancer: Challenges and Responses". Instituto Carso de la Salud, Fundación Mexicana para la Salud,AC. Mexico City. November 18th and 19th. 2008 [Consulted february 5, 2009]. Available at: http://www.tomateloapecho.org.mx/Seminarioint.php. 4. Shapiro, M. Life in the Balance: My journey with breast cancer.Toronto: HarperCollins Publishers Ltd, 2006. 